\title{
Integrating International Graduate Students on Campus: The Perspectives of Student Affairs Professionals
}

\author{
Rachal Etshim \\ Western Michigan University, United States of America \\ Email: etshim.rachal@wmich.edu. \\ Address: 638 South Drake Road Apt V1, Kalamazoo, MI 49009
}

\section{Introduction}

Higher education institutions in the United States (US) recruit international students as part of their internationalization strategies. The overall number of international students enrolled in American universities and colleges between 2017 and 2018 increased by 1.5 percent compared to the previous year, totaling over 1 million international students (Institute of International Education 2018). Of this total, 382,983 are international graduate students.

International graduate students are good resources for the internationalization and economy of higher education institutions in the US (Urban and Palmer 2014, 305-324) and, despite the reduction in the number of visas approved and job prospects, their numbers continue to grow (Almurideef 2016, 1-48). These students come from different countries, have different cultural backgrounds and needs, and face different challenges that student affairs professionals at host institutions must address to integrate them into campus (Harper and Hurtado 2007, 7-24; Lee and Rice 2007, 381-409). Moreover, the needs and challenges of international students differ depending on their level of studies, undergraduate vs. graduate (Rai 2002, 21-34). While student affairs professionals are often the first contacts for all international students, and they play a key role in the integration and development of international graduate students on campus (Brandenburg 2016, 15-17), most higher education institutions and their student affairs units today are not yet prepared to serve international graduate students (Arokiasamy 2011, 73-81; Burdzinski 2014, 1-137; Di Maria 2012, 1-228; Moswela and Mukhopadhyay 2011, 307-319; Yakaboski and Perozzi 2018, 21).

The purpose of this study is to understand the perspectives of student affairs professional about their role in integrating international graduate students into campus and the policies, services, programs, and other elements they consider most helpful in integrating these students.

\section{Methodology}

For the purpose of this study, I will use a qualitative method. Creswell $(2013,15-42)$ defined qualitative research as a broad approach to the study of social phenomena. My goal is to understand perspectives of student affairs professionals about their role in integrating international graduate into campus, the policies, services, programs, and other elements these student affairs professionals consider most helpful in integrating these students. In order to get a deep understanding of those perspectives, I need to give voice to student affairs professionals, listen to their experiences and interpretation of events and activities related to the integration of international graduate students. A qualitative research study is the most suitable method to get an in-depth understanding of a social phenomenon to answer the research questions, and it relies on the direct experiences of human beings (Creswell and Poth 2017, 41; Marshall and Rossman 2016, 15). 
I will conduct an instrumental case study, which allows me to focus on an issue or a concern, such as the integration of international graduate students, and then selects one bounded case to illustrate this issue (Baxter 2008; Stake 2005, 544-559; Yazan, 2015, 134-152). The institution where I will conduct this study is located in the Midwestern United States and it is committed to internationalization. I will use a semi-structured interview to allow for questions that may provide further meaning from participants (Creswell 2013, 145). The interview protocol was tested with real participants to ensure that questions were appropriate and relevant. I will need 10-15 student affairs professionals and other support staff who have served or serve international graduate students. In addition to interviews, I will gather data from documentation, archival records, interviews, site observations, and physical artifacts (Yin 2009, 99-124). I will maintain document summary forms to help organize information obtained from documents. I will also conduct site observations to gather information and first-hand experience of the research setting, understand and capture the context within which student affairs professionals and international graduate students interact.

\section{Data Analysis}

I will use inductive thematic analysis to examine the perspectives of each participant. Inductive thematic analysis is a data analysis method that can be widely used across a range of epistemologies and research questions (King 2004, 257-270). It is a method for identifying, analyzing, organizing, describing, and reporting themes found within a data set (Braun and Clarke 2006). I will use the following steps to thematically analyze my data: familiarize myself with the data; generate codes; search for themes; reviews themes; define and name themes; and producing the report (Braun and Clarke 2006, 77-101).

\section{Contribution of the Research to Comparative and International Higher Education}

A need exists to gain the perspectives of the perspectives of student affairs professionals on integrating international graduate students into campus and the policies, services, programs, and other elements they consider most helpful in integrating these students. Other higher education institutions around the world that desire to enroll international graduate students may use the findings of this study to develop training for their student affairs professionals to meet the needs and challenges of this category of students. Researchers or practitioners interested in international students and student affairs may use the findings of this study as a baseline of information. Finally, this study will contribute to the limited body of research that address the roles of student affairs professionals in the internationalization of higher education.

\section{The Main Take Away of the Research}

The integration of international graduate students depends on student affairs professionals' readiness to serve people from different socio-cultural backgrounds. Therefore, higher education institutions and specific student affairs' units should provide continuous intercultural trainings to student affairs professionals so they can better serve the entire campus community and help the institution reach its internationalization goals.

\section{References}

Almurideef, Raja. 2016. "The challenges that international students face when integrating into." PhD, Rowan University. 
Arokiasamy, Anantha. 2011. "An analysis of globalization and higher education in Malaysia." Australian Journal of Business and Management Research 1(9): 73-81.

Baxter, Pamela, and Jack Susan. 2008. "Qualitative case study methodology: Study design and implementation for novice researchers." The Qualitative Report 13(4): 544-559.

Brandenburg, Uwe. 2016. "The value of administrative staff for internationalization." International Higher Education 85: 15-17. doi:10.6017/ihe.2016.85.9239.

Braun, Virginia, and Clarke Victoria. 2006. "Using thematic analysis in psychology." Qualitative Research in Psychology 3(2): 77-101. http://dx.doi.org/10.1191/1478088706qp063oa

Burdzinski, Donna. 2016. "Attitudes about Globalization, Internationalization, and The Role of Student Affairs Administrators in Internationalizing Florida's Community and State Colleges." PhD, University of South Florida.

Creswell, John. 2013. Qualitative inquiry and research design: Choosing among five approaches. $3^{\text {rd }}$ edition. Thousand Oaks, CA: Sage.

Creswell, John, and Poth Cheryl. 2018. Qualitative inquiry \& research design: Choosing among five approaches. $4^{\text {th }}$ edition. Thousand Oaks, CA: Sage.

Di Maria, David. 2012. "Factors Affecting views of Campus Services for International Students Among Student Affairs Administrators at Five Public Universities in Ohio." PhD, University of Minnesota.

Harper, Shaun, and Hurtado Sylvia. 2007. "Nine themes in campus racial climates and implications for institutional transformation." New Directions for Student Services 2007 (120): 7-24. https://doi.org/10.1002/ss.254

Institute of International Education. "Open doors report (USA)." Updated November 13, 2018. https://www.iie.org/Research-and-Insights/Open-Doors/Open-Doors-2018-Media-Information.

Lee, Jenny, and Rice Charles. 2007. "Welcome to America? International student perceptions of discrimination." Higher Education 53(3): 381-409. https://doi.org/10.1007/s10734-005-4508-3

Marshall, Catherine, and Rossman Gretchen. 2016. Designing qualitative research. $6^{\text {th }}$ edition. Thousand Oaks, CA: Sage.

Moswela, Emmanuel, and Mukhopadhyay Sourav. 2010. "Asking for too much? The voices of students with disabilities in Botswana." Disability and Society 26(3): 307-319. https://doi.org/10.1080/09687599.2011.560414

King, Nigel. 2004. "Using Templates in the Thematic Analysis of text." In Essential Guide to Qualitative Methods in Organizational Research, edited by Cassell, Catherine, and Gillian Symon, 257-270. London, UK: Sage.

Rai, Gauri. 2002. "Meeting the educational needs of international students: A perspective from U.S schools." International Social Work 45(1): 21-34. https://doi.org/10.1177/0020872802045001312.

Stake, Robert. 2005. "Qualitative Case Studies." In The Sage Handbook of Qualitative Research, edited by Denzin, Norman, and Lincoln Yvonna, 443-466. Thousand Oaks, CA: Sage.

Urban, Ewa, and Palmer Bierlein. 2014. "International students as a resource for internationalization of higher education." Journal of Studies in International Education 18(4): 305-324. https://doi.org/10.1177/1028315313511642.

Yakaboski, Tamara, and Perozzi Brett. 2018. Internationalizing US Student Affairs Practice. New York: Routledge.

Yazan, Bedrettin. 2015. "Three approaches to case study methods in education: Yin, Merriam, and Stake." The Qualitative Report 20(2): 134-152.

Yin, Robert. 2009. Case study research: Design and methods. 4th edition. Thousand Oaks, CA: Sage. 